\title{
PNPLA3 gene and kidney disease
}

\begin{abstract}
Alessandro Mantovani*, Chiara Zusi
Section of Endocrinology, Diabetes and Metabolism, University and Azienda Ospedaliera Universitaria Integrata of Verona, 37126 Verona, Italy
\end{abstract}

*Correspondence: Alessandro Mantovani, Section of Endocrinology, Diabetes and Metabolism, University and Azienda Ospedaliera Universitaria Integrata, Piazzale Stefani, 37126 Verona, Italy. alessandro.mantovani@univr.it Academic Editor: Yingyong Zhao, Northwest University, China

Received: November 22, 2019 Accepted: December 31, 2019 Published: February 29, 2020

Cite this article: Mantovani A, Zusi C. PNPLA3 gene and kidney disease. Explor Med. 2020:42-50. https://doi.org/10.37349/ emed.2020.00004

\begin{abstract}
Chronic kidney disease (CKD) is a disease regularly seen in clinical practice. At present, CKD is described as a change of kidney structure and/or function and it is classified in relation to cause, values of glomerular filtration rate and albuminuria category. Seeing that CKD is closely linked to the development of end-stage renal disease and other comorbidities, the determination of additional independent predictors for CKD is clinically necessary. At present, there is evidence associating non-alcoholic fatty liver disease (NAFLD) with CKD, thereby suggesting that NAFLD patients may require intensive surveillance to reduce their risk of CKD. In 2008, genome-wide association studies documented an association between the variant rs738409 (C > G p.I148M) in the patatin-like phospholipase domain containing 3 (PNPLA3) gene (mainly implicated in the lipid regulation) and the entire spectrum of NAFLD (i.e., liver steatosis, non-alcoholic steatohepatitis, fibrosis, and hepatocellular carcinoma). In the last years, accumulating epidemiological evidence suggests the existence of a relationship between PNPLA3 rs738409 and risk of CKD, indicating that rs738409 may also contribute to the kidney injury. This is of particular scientific interest, as such association may explain, at least in part, the epidemiological association between liver and kidney disease. In this narrative review, we will discuss the accumulating evidence regarding the association between PNPLA3 rs738409 and risk of CKD, the putative biological mechanisms underpinning such relationship, and the possible future perspective.
\end{abstract}

\section{Keywords}

Patatin-like phospholipase domain containing 3, kidney disease, chronic kidney disease, non-alcoholic fatty liver disease, non-alcoholic steatohepatitis

\section{Introduction}

Chronic kidney disease (CKD) is a progressive disease habitually seen in clinical practice [1]. It is currently described as an alteration of kidney structure and/or function and it is classified on cause, values of glomerular filtration rate (GFR) and albuminuria category [1]. It is estimated that the prevalence of CKD is approximately $13 \%$ among the adults of the general population worldwide [2]. In this regard, for instance, 
the US Renal Data System has documented that in 2014 roughly 670,000 adults received a renal replacement therapy [3]. Alarmingly, this number is believed to markedly rise by $2030 / 2050$ [3]. Of note, the presence of CKD determines severe repercussions for multiple organs, seeing that it increases the risk of developing end-stage renal disease, cardiovascular disease and other serious comorbidities, thereby determining also a relevant increase in costs for the health systems [1,4]. For these reasons, the appropriate identification of additional non-conventional independent predictors for CKD is essential.

The patatin-like phospholipase domain-containing protein-3 (PNPLA3) is particularly expressed on the lipid droplets of hepatocytes and is closely implicated in the development and progression of non-alcoholic fatty liver disease (NAFLD) [5-7], which is currently the most frequent chronic liver disease worldwide [8]. In this regard, it is important to highlight that NAFLD affects roughly $25 \%$ of adults, about $70 \%$ of patients with type 2 diabetes (T2DM) and virtually all obese individuals [8]. In the last decade, additionally, it is clearly demonstrated that NAFLD (as detected by imaging or liver biopsy) is associated with hepatic complications, but also with extra-hepatic complications, including cardiovascular disease [9]. The rs738409 C > G single nucleotide polymorphism, encoding for the I148M protein variant PNPLA3, is a key genetic determinant of the risk of NAFLD and its advanced forms, including non-alcoholic steatohepatitis (NASH), advanced fibrosis and hepatocellular carcinoma [5-7].

In the last 5-10 years, several observational reports have documented that imaging-diagnosed NAFLD is independently associated with an increased risk of developing CKD in patients with and without T2DM [10-23]. In addition, accumulating evidence now suggests that the rs738409 $\mathrm{G}$ allele is associated with lower values of estimated glomerular filtration rate (eGFR) as well as with a higher risk of CKD in adults but also in adolescents and children, even after adjustment for the presence of NAFLD and multiple CKD risk factors [13, 24-30]. This association may explain, at least in part, the epidemiological association between liver and kidney disease [10-23].

In our narrative review, we will discuss: (a) the accumulating evidence regarding the association between PNPLA3 rs738409 and risk of CKD, (b) the putative biological mechanisms underpinning such relationship, and (c) the possible future perspective.

\section{PNPLA3 in liver disease}

The PNPLA3 rs738409 C $>\mathrm{G}$ is a genetic determinant closely linked to the entire spectrum of NAFLD across multiple different patient populations [5-7]. The PNPLA3 rs738409 was found as risk locus for NAFLD in 2008 through genome-wide association studies (GWAS) [31]. Subsequently, several experimental studies have suggested that PNPLA3 is an enzyme implicated in the lipid regulation with a triacylglycerol lipase and acylglycerol 0 -acyltransferase activity and a retinyl ester activity, especially in the hepatic stellate cells [32-36]. The biological mechanism for the development and progression of NAFLD seems to be related to the accumulation of the 148M mutated protein on the lipid droplet of hepatocytes, thereby determining relevant alterations of lipid remodeling and concurring to the liver injury [5-7].

Several variants in PNPLA3 gene have been also found by several GWAS as risk locus for hepatic cirrhosis due to alcohol abuse $[5,37,38]$ or chronic infection by hepatitis B and C virus $[5,39,40]$. Of note, the PNPLA3 (rs738409 C > G) is closely associated with severe steatosis and even liver carcinogenesis also in patients with alcoholic and non-alcoholic cirrhosis [5, 37-40]. Findings obtained in patients with HCV-related HCC remain, however, debatable [5].

Most studies reported that PNPLA3 is not linked with body mass index, lipids, plasma glucose levels or insulin resistance [5]. This aspect was also corroborated by a recent meta-analysis involving roughly 7,000 individuals with NAFLD [41]. In addition, although it is known that NAFLD is closely associated with an increased risk of T2DM, cardiovascular disease and CKD [8-13], data available so far suggest only a fair overlap in genome-wide significant associations $[6,42]$. Specifically, some variants related to NAFLD risk, including rs738409, show divergent effects between the traditional metabolic alterations and the development of diseases, especially for cardiovascular complications [6, 42]. However, at present, 
accumulating observational data for rs738409 seems to indicate that this single nucleotide polymorphism might be associated to the presence of CKD [24-30].

\section{Observational data regarding the role of PNPLA3 on the risk of CKD}

Increasing evidence now supports the existence of an association between PNPLA3 G/G genotype and decreasing eGFR values or higher prevalence of CKD across different patient population, even after controlling for many CKD risk factors and for the presence of NAFLD [24-30] (Table 1). For instance, in a cross-sectional study of 740 Japanese individuals (about $16 \%$ of whom had NAFLD on ultrasonography), Oniki et al. [24], showed that patients with rs738409 G/G genotype had lower eGFR values than those with G/C or C/C genotypes, even after adjustment for multiple cardio-renal and metabolic risk factors. This association was further replicated in a longitudinal sub-analysis including roughly 350 non-obese patients followed for nearly 6 years [24]. In another cross-sectional study of approximately 200 Caucasian non-obese non-diabetic adults, Musso et al. [25], showed that rs738409 G/G genotype was linked to lower values of eGFR $_{\text {CKD-EPI }}$ as well as to higher levels of abnormal albuminuria. Additionally, in a recent cross-sectional study of nearly 100 Caucasian post-menopausal women with T2DM (approximately 44\% of whom had NAFLD as detected by fatty liver index $\geq 60$ ), Mantovani et al. [26], showed that rs738409 G/G genotype was linked to lower eGFR CKD-EPI $_{\text {values }}$ and higher risk of prevalent CKD, even after adjustment for several cardio-metabolic risk factor and the presence of NAFLD. Recently, in a cross-sectional study of 227 Chinese adults with NAFLD on histology, Sun et al. [27], reported that PNPLA3 GG genotype was associated with a higher risk of prevalent CKD, abnormal albuminuria or higher levels of urinary neutrophil gelatinase-associated lipocalin (a new marker of renal tubular injury), regardless of age, sex, hypertension, T2DM and severity of NAFLD.

These findings were also replicated in some cohorts of children and adolescents [28, 29], although not in all [30]. For instance, in a sample of nearly 140 overweight children with NAFLD on histology, Targher et al. [28], reported that rs738409 G/G genotype was independently associated with both decreasing e-GFR and increasing $24 \mathrm{~h}$ urinary protein excretion. Another cross-sectional study involving 591 Caucasian children with obesity, it was documented that those with G/G genotype had significantly lower eGFR levels than those with G/C or C/C genotypes [29]. Conversely, in a recent cross-sectional study of 230 Caucasian overweight/obese children, Di Costanzo et al. [30], found that children with G/G genotype did not have lower eGFR levels than those with $\mathrm{C} / \mathrm{G}$ or $\mathrm{C} / \mathrm{C}$ genotypes. However, as recognized by the same authors, it is possible to speculate that the relatively low frequency of PNPLA3 G/G genotype in that study and the inclusion of children with and without NAFLD may provide a neutral relationship between NAFLD, PNPLA3 rs738409 and renal function [30].

Collectively, however, these observational data supported the notion that rs738409 G/G genotype is associated with an increased risk of CKD. This association seems to remain statistically significant in patients with and without T2DM even after controlling for several CKD risk factors and the presence of NAFLD. However, some relevant aspects of the aforementioned observational studies should be mentioned here. First, all studies used different creatinine-based GFR estimating equations. We believe that the use of direct measurements of GFR would have been more appropriate, as it is known that the equations based on serum levels of creatinine might be not accurate in estimating GFR in some specific patients, including those with obesity or advanced liver disease [13]. Second, NAFLD was diagnosed by imaging techniques or specific indirect markers and, rarely, by histology (which is the "gold standard" for the diagnosis of NAFLD [8, 9]). Third, no further information was available regarding the renal pathology. Fourth, at present, no information regarding the association between PNPAL3 rs738409 and CKD is available in non-NAFLD patient cohorts. We believe that this aspect should be timely investigated in order to corroborate the accumulating evidence regarding the potential effect of rs738409 on the kidney function. Lastly, PNPLA3 variant in association to CKD has not been identified by GWAS studies yet.

\section{Experimental data on the effect of PNPLA3 rs738409 in the renal function}

To date, the mechanisms underpinning the relationship between PNPLA3 rs738409 and impaired kidney function are poorly understood. In the literature, it is still discussed whether the G allele of rs738409 exerts 
Table 1. Observational studies on the relationship between patatin-like phospholipase domain-containing protein-3 rs738409 genotype and kidney function (ordered by publication year and study population)

\begin{tabular}{|c|c|c|c|c|c|c|}
\hline $\begin{array}{l}\text { Author, } \\
\text { Reference }\end{array}$ & $\begin{array}{l}\text { Study characteris- } \\
\text { tics }\end{array}$ & $\begin{array}{l}\text { Diagnosis of } \\
\text { NAFLD }\end{array}$ & $\begin{array}{l}\text { PNPLA3 rs738409 } \\
\text { genotypes }\end{array}$ & $\begin{array}{l}\text { Glomerular } \\
\text { filtration rate } \\
\text { formulas } \\
\end{array}$ & $\begin{array}{l}\text { Statistical ad- } \\
\text { justments }\end{array}$ & Main results \\
\hline \multicolumn{7}{|l|}{ Adults } \\
\hline $\begin{array}{l}\text { Oniki et al. } \\
{[24]}\end{array}$ & $\begin{array}{l}\text { Cross-sectional and } \\
\text { retrospective longi- } \\
\text { tudinal studies: } 740 \\
\text { and } 393 \text { Japanese } \\
\text { participants (followed } \\
\text { for } 5.5 \text { years) respec- } \\
\text { tively, during a health } \\
\text { screening program }\end{array}$ & $\begin{array}{l}\text { Utrasonogra- } \\
\text { phy }\end{array}$ & $\begin{array}{l}\text { G/G: } n=139 \text { pa- } \\
\text { tients; G/C: } n=399 \\
\text { patients; C/C: } n= \\
202 \text { patients }\end{array}$ & $\begin{array}{l}\text { Japanese eGFR } \\
\text { equation }\end{array}$ & $\begin{array}{l}\text { Age, gender, body } \\
\text { mass index; dia- } \\
\text { betes, hyperten- } \\
\text { sion, dyslipidemia, } \\
\text { fatty liver }\end{array}$ & $\begin{array}{l}\text { Carriers of G/ } \\
\text { G genotype and } \\
\text { normal weight had } \\
\text { reduced eGFR } \\
\text { levels than those } \\
\text { with } C / C \text { or } C / G \\
\text { genotypes }\end{array}$ \\
\hline $\begin{array}{l}\text { Musso et } \\
\text { al. [25] }\end{array}$ & $\begin{array}{l}\text { Cross-sectional } \\
\text { study: } 202 \text { non- } \\
\text { obese and non-di- } \\
\text { abetic individuals } \\
\text { ( } 61 \text { with biopsy-con- } \\
\text { firmed NAFLD) }\end{array}$ & Biopsy & $\begin{array}{l}\text { G/G or G/C: } 112 \\
\text { patients; C/C: } n=90 \\
\text { patients }\end{array}$ & $\begin{array}{l}\text { Chronic kidney } \\
\text { disease epidemi- } \\
\text { ology (CKD-EPI) } \\
\text { collaboration } \\
\text { equation }\end{array}$ & $\begin{array}{l}\text { Age, gender, body } \\
\text { mass index; meta- } \\
\text { bolic syndrome }\end{array}$ & $\begin{array}{l}\text { Carriers of } G / G \\
\text { or } C / G \text { genotypes } \\
\text { were linked to } \\
\text { higher risk of albu- } \\
\text { minuria and CKD } \\
\text { than } C / C \text { genotype }\end{array}$ \\
\hline $\begin{array}{l}\text { Mantovani } \\
\text { et al. [26] }\end{array}$ & $\begin{array}{l}\text { Cross-sectional } \\
\text { study: } 101 \text { Cauca- } \\
\text { sian post-menopaus- } \\
\text { al women with type } 2 \\
\text { diabetes }\end{array}$ & $\begin{array}{l}\text { FLI } \geq 60 \\
\text { (ultrasonog- } \\
\text { raphy in a } \\
\text { subset of } \\
\text { patients) }\end{array}$ & $\begin{array}{l}\text { G/G: } n=8 \text { patients; } \\
\text { G/C: } n=41 \text { patients; } \\
\text { C/C: } n=52 \text { patients }\end{array}$ & $\begin{array}{l}\text { CKD-EPI collab- } \\
\text { oration equation }\end{array}$ & $\begin{array}{l}\text { Age, diabetes du- } \\
\text { ration, hemoglobin } \\
\text { A1c, insulin-re- } \\
\text { sistance, systolic } \\
\text { blood pressure, } \\
\text { hypertension } \\
\text { treatment, FLI }\end{array}$ & $\begin{array}{l}\text { Carriers of G/ } \\
\text { G genotype had } \\
\text { reduced eGFR } \\
\text { levels and higher } \\
\text { prevalence of CKD } \\
\text { than to C/C or C/G } \\
\text { genotypes }\end{array}$ \\
\hline $\begin{array}{l}\text { Sun et al. } \\
\text { [27] }\end{array}$ & $\begin{array}{l}\text { Cross-sectional } \\
\text { study: } \\
227 \text { Chinese patients } \\
\text { with NAFLD }\end{array}$ & biopsy & $\begin{array}{l}\text { G/G: } n=14 \text { patients; } \\
\text { G/C: } n=31 \text { patients; } \\
\text { C/C: } n=30 \text { patients }\end{array}$ & $\begin{array}{l}\text { CKD-EPI collab- } \\
\text { oration equation }\end{array}$ & $\begin{array}{l}\text { Age, sex, body } \\
\text { mass index; waist } \\
\text { circumference, } \\
\text { hyperuricemia, } \\
\text { insulin-resistance, } \\
\text { hypertension, } \\
\text { diabetes, NASH, } \\
\text { liver fibrosis }\end{array}$ & $\begin{array}{l}\text { Patients with } \\
\text { NAFLD and normal } \\
\text { liver enzymes, who } \\
\text { carried the PNP- } \\
\text { LA3 rs738409 G al- } \\
\text { lele, were at higher } \\
\text { risk of glomerular } \\
\text { and tubular injury }\end{array}$ \\
\hline \multicolumn{7}{|c|}{ Children and adolescents } \\
\hline $\begin{array}{l}\text { Targher et } \\
\text { al. [28] }\end{array}$ & $\begin{array}{l}\text { Cross-sectional } \\
\text { study: } 142 \text { Cauca- } \\
\text { sian children and } \\
\text { adolescents with } \\
\text { NAFLD }\end{array}$ & Biopsy & $\begin{array}{l}\text { G/G: } n=45 \text { patients; } \\
\text { G/C: } n=56 \text { patients; } \\
\text { C/C: } n=41 \text { patients }\end{array}$ & $\begin{array}{l}\text { Bedside } \\
\text { Schwartz equa- } \\
\text { tion }\end{array}$ & $\begin{array}{l}\text { Age, sex, systolic } \\
\text { blood pressure, } \\
\text { measures of adi- } \\
\text { posity, insulin-re- } \\
\text { sistance, NASH, } \\
\text { liver fibrosis }\end{array}$ & $\begin{array}{l}\text { Carriers of G/G } \\
\text { genotype had re- } \\
\text { duced eGFR levels } \\
\text { and higher protein- } \\
\text { uria than C/C or C/ } \\
\text { G genotypes }\end{array}$ \\
\hline $\begin{array}{l}\text { Marzuillo et } \\
\text { al. [29] }\end{array}$ & $\begin{array}{l}\text { Cross-sectional } \\
\text { study: } \\
591 \text { Caucasian } \\
\text { obese children }\end{array}$ & $\begin{array}{l}\text { Ultrasonogra- } \\
\text { phy }\end{array}$ & $\begin{array}{l}\text { G/G: } n=87 \text { patients; } \\
\text { G/C: } n=219 \text { pa- } \\
\text { tients; C/C: } n=285 \\
\text { patients }\end{array}$ & $\begin{array}{l}\text { Bedside } \\
\text { Schwartz equa- } \\
\text { tion }\end{array}$ & $\begin{array}{l}\text { Gender, duration } \\
\text { of obesity, alanine } \\
\text { transaminase, } \\
\text { insulin resistance, } \\
\text { lipids }\end{array}$ & $\begin{array}{l}\text { Carriers of G/G } \\
\text { genotype had re- } \\
\text { duced eGFR levels } \\
\text { than those with C/ } \\
\text { C or C/G geno- } \\
\text { types }\end{array}$ \\
\hline $\begin{array}{l}\text { Di Costan- } \\
\text { zo et al. } \\
{[30]}\end{array}$ & $\begin{array}{l}\text { Cross-sectional } \\
\text { study: } 230 \text { Cauca- } \\
\text { sian overweight/ } \\
\text { obese children }\end{array}$ & $\begin{array}{l}\text { Magnetic } \\
\text { resonance } \\
\text { imaging }\end{array}$ & $\begin{array}{l}\text { G/G: } n=22 \text { patients; } \\
\text { G/C: } n=100 \text { pa- } \\
\text { tients; C/C: } n=108 \\
\text { patients }\end{array}$ & $\begin{array}{l}\text { Bedside } \\
\text { Schwartz equa- } \\
\text { tion }\end{array}$ & $\begin{array}{l}\text { Age, sex, puber- } \\
\text { tal status, waist } \\
\text { circumference, } \\
\text { diastolic blood } \\
\text { pressure, NAFLD }\end{array}$ & $\begin{array}{l}\text { Carriers of G/G } \\
\text { genotype did not } \\
\text { have lower eGFR } \\
\text { levels than those } \\
\text { with } \mathrm{C} / \mathrm{C} \text { or } \mathrm{C} / \mathrm{G} \\
\text { genotypes }\end{array}$ \\
\hline
\end{tabular}

FLI: fatty liver index

a direct adverse impact on kidney function or whether it indirectly influences the kidney function by hepatic lipid status. Seeing that the presence of NAFLD is associated to unfavourable metabolic profile with the subsequent decline of renal function, Marzuillo et al. [29], have speculated on the existence of a vicious circle in which the PNPLA3 148M allele may predispose individuals to NAFLD, and, in turn, NAFLD may boost the (adverse) effect of the PNPLA3 148M allele on renal function. Corroborating this hypothesis, Pirazzi et al. [35], performed an in vitro study reporting that PNPLA3 was expressed in adipose tissue, but also in the kidneys. In addition, Hoekstra et al. [43], reported that the expression of PNPLA3 gene in the adipose tissue of mice was approximately 50-100-fold higher than that observed in the liver tissue. Interestingly, in that study, 
the difference in expression of PNPLA3 gene between adipose and liver tissue was increased when mice were fed with Western-type diet (which can be considered a condition of lipid excess), thereby suggesting that adiposity may amplify the genetic impact of PNPLA3 [43]. In this context, as reported by Stender et al. [44], it is important to note that the gene-adiposity interaction may have a relevant role in the development and progression of NAFLD. In line with this view, some authors have speculated that in the kidney the expression of PNPLA3 may be enhanced in condition of lipid excess, leading to the accumulation of lipids in podocytes but also in renal mesangial or tubular cells [25]. In this context, it is important to note that the accumulation of lipids in the kidney cells may also promote insulin resistance, oxidative stress and pro-inflammatory state, thereby leading to renal structural and functional alterations that may additionally weaken the integrity of glomeruli [45] (Figure 1).

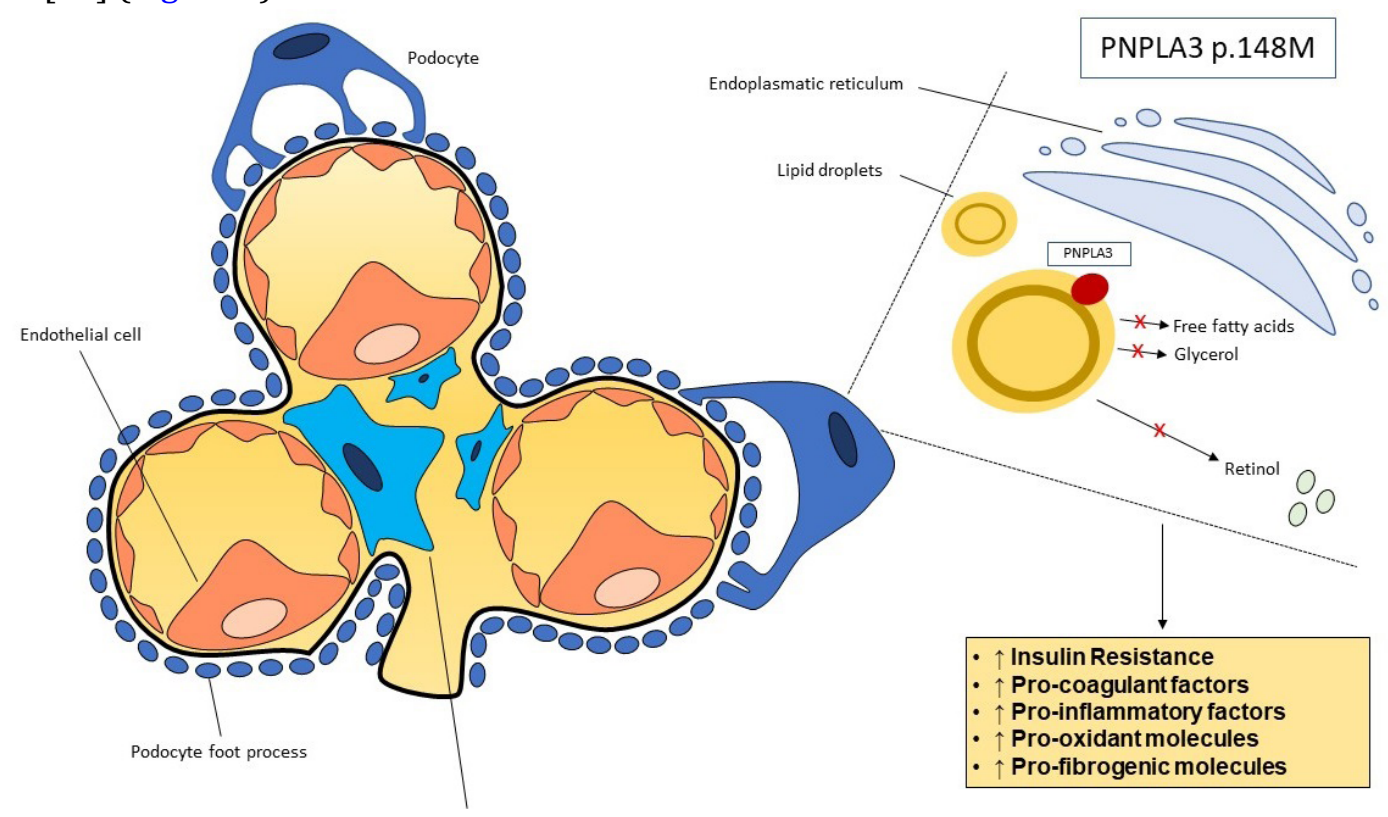

Mesangial cell

Figure 1. Putative mechanisms underpinning the association between PNPLA3 rs738409 genotype and kidney function. PNPLA3 has a hydrolase activity regarding triglycerides and retinyl esters. It is thought that in mesangial cells and podocytes PNPLA3 might be located in the lipid droplets. The I148M mutation leads a diminution of function of the protein with an excessive internment of fat and retinol in cells. The accumulation of lipids and retinol in the kidney cells may promote insulin resistance, oxidative stress and pro-inflammatory cytokines, thus resulting in renal structural and functional alterations

Fat accumulation and lipotoxicity may not be the only mechanisms proposed to influence the direct or indirect action of PNPLA3 on the impaired kidney function. Romeo et al. [46], for instance, speculated that the $G$ variant of rs738409 may influence the glomerular filtration through an activation of kidney pericytes, thereby concurring to the development of kidney fibrosis. At present, indeed, it is believed that kidney fibrosis (along with chronic inflammation) is one of most important pathological process implicated in CKD $[1,12,46]$. Future studies are needed to elucidate the biological mechanisms underlying the relationship between PNPLA3 rs738409 and impaired kidney function.

\section{Future perspective}

Seeing that several epidemiological studies have documented that NAFLD is independently associated with higher risk of CKD, it remains to establish whether PNPLA3 variants are active contributors or innocent bystanders. Indeed, the issue of whether $\mathrm{G}$ allele risk is a strong mediator of the relationship between NAFLD and CKD becomes more and more apparent. The Mendelian randomization approach will help to make causal inferences.

At present, there are not formal recommendations for patients with several specific gene variants that predispose to NAFLD and its hepatic or extra-hepatic complications, including CKD. However, it is reasonable to assume that future and potential therapeutic strategies focused on personalized medicine will include PNPLA3 genetic classification test [13]. Although many clinical trials are still ongoing to assess the individual 
response to NAFLD intervention in function of gene polymorphisms, accumulating data now suggest that $148 \mathrm{M}$ carriers may respond differently to lifestyle and drug intervention $[6,47]$. Therefore, it is likely that therapeutic interventions that decreased PNPLA3 I148M levels may ameliorate the severity of NAFLD and the consequences of its complications.

\section{Conclusions}

CKD is closely associated with all-cause mortality as well as with the development of end-stage renal disease, cardiovascular disease or other serious comorbidities [1]. Hence, the identification of further independent predictors for CKD is crucial in clinical practice. At present, there is strong evidence linking NAFLD and CKD, indicating that patients with NAFLD could need more intensive surveillance and treatment in order to reduce their risk of developing CKD [8-22]. Additionally, accumulating data also suggest the existence of an association between PNPLA3 rs738409 gene variant (which is strongly linked to the development of NAFLD and its advanced forms) and risk of CKD [23-29], thereby suggesting that PNPLA3 may directly influence the kidney injury [44]. This may also clarify the epidemiological association between liver and kidney disease. The pathophysiological mechanisms linking PNPLA3 gene, NAFLD and CKD seem to be complex and require additional studies to be elucidated. The identification of such mechanisms may result in novel therapeutic targets for the treatment of CKD. Meanwhile, it is reasonable to suppose that patients with NAFLD should be also better genotyped, given the potential role of the PNPLA3 gene on the risk of NAFLD and CKD.

\section{Abbreviations}

CKD: chronic kidney disease

eGFR: estimated glomerular filtration rate

FLI: fatty liver index

GFR: glomerular filtration rate

GWAS: genome-wide association studies

NAFLD: non-alcoholic fatty liver disease

NASH: non-alcoholic steatohepatitis

PNPLA3: patatin-like phospholipase domain containing 3

T2DM: type 2 diabetes

\section{Declarations}

\section{Author contributions}

$\mathrm{AM}$ and $\mathrm{CZ}$ contributed conception and design of the study; AM and CZ wrote the first draft of the manuscript. All authors contributed to manuscript revision, read and approved the submitted version.

\section{Conflicts of interest}

The authors declare that they have no conflicts of interest.

\section{Ethical approval}

Not applicable.

\section{Consent to participate}

Not applicable.

\section{Consent to publication}

Not applicable. 
Availability of data and materials

Not applicable.

Funding

Not applicable.

\section{Copyright}

(c) The Author(s) 2020.

\section{References}

1. Webster AC, Nagler EV, Morton RL, Masson P. Chronic kidney disease. Lancet. 2017;389:1238-52.

2. Hill NR, Fatoba ST, Oke JL, Hirst JA, O'Callaghan CA, Lasserson DS, Hobbs FD. Global prevalence of chronic kidney disease-a systematic review and meta-analysis. PLoS One. 2016;11:e0158765.

3. Stevens PE, Levin A; Kidney Disease: Improving Global Outcomes Chronic Kidney Disease Guideline Development Work Group Members. Evaluation and man-agement of chronic kidney disease: synopsis of the kidney disease: improving global outcomes 2012 clinical practice guideline. Ann Intern Med. 2013;158:825-30.

4. Zoccali C, Vanholder R, Massy ZA, Ortiz A, Sarafidis P, Dekker FW, et al; Europe-an Renal and Cardiovascular Medicine (EURECA-m) Working Group of the Eu-ropean Renal Association-European Dialysis Transplantation Association (ERA-EDTA). The systemic nature of CKD. Nat Rev Nephrol. 2017;13:344-58.

5. Trépo E, Romeo S, Zucman-Rossi J, Nahon P. PNPLA3 gene in liver diseases. J Hepatol. 2016;65:399-412.

6. Eslam M, George J. Genetic contributions to NAFLD: leveraging shared genetics to uncover systems biology. Nat Rev Gastroenterol Hepatol. 2020;17:40-52.

7. Eslam M, Valenti L, Romeo S. Genetics and epigenetics of NAFLD and NASH: clinical impact. J Hepatol. 2018;68:268-79.

8. Younossi ZM, Koenig AB, Abdelatif D, Fazel Y, Henry L, Wymer M. Global epi-demiology of nonalcoholic fatty liver disease-meta-analytic assessment of prev-alence, incidence, and outcomes. Hepatology. 2016;64:73-84.

9. Byrne CD, Targher G. NAFLD: a multisystem disease. J Hepatol. 2015;62:S47-64.

10. Musso G, Gambino R, Tabibian JH, Ekstedt M, Kechagias S, Hamaguchi M, et al. Association of nonalcoholic fatty liver disease with chronic kidney disease: a systematic review and meta-analysis. PLoS Med. 2014;11:e1001680.

11. Mantovani A, Zaza G, Byrne CD, Lonardo A, Zoppini G, Bonora E, et al. Nonalco-holic fatty liver disease increases risk of incident chronic kidney disease: a sys-tematic review and meta-analysis. Metabolism. 2018;79:64-76.

12. Targher G, Byrne CD. Non-alcoholic fatty liver disease: an emerging driving force in chronic kidney disease. Nat Rev Nephrol. 2017;13:297-310.

13. Mantovani A, Zusi C, Dalbeni A, Grani G, Buzzetti E. Risk of kidney dysfunction in NAFLD. Curr Pharm Des. 2019; [Epub ahead of print].

14. Targher G, Chonchol M, Bertolini L, Rodella S, Zenari L, Lippi G, et al. Increased risk of CKD among type 2 diabetics with nonalcoholic fatty liver disease. J Am Soc Nephrol. 2008;19:1564-70.

15. Arase Y, Suzuki F, Kobayashi M, Suzuki Y, Kawamura Y, Matsumoto N, et al. The development of chronic kidney disease in Japanese patients with non-alcoholic fatty liver disease. Intern Med. 2011;50:1081-7.

16. Huh JH, Kim JY, Choi E, Kim JS, Chang Y, Sung KC. The fatty liver index as a pre-dictor of incident chronic kidney disease in a 10-year prospective cohort study. PLoS One. 2017;12:e0180951. 
17. Targher G, Mantovani A, Pichiri I, Mingolla L, Cavalieri V, Mantovani W, et al. Nonalcoholic fatty liver disease is independently associated with an increased incidence of chronic kidney disease in patients with type 1 diabetes. Diabetes Care. 2014;37:1729-36.

18. Shen ZW, Xing J, Wang QL, Faheem A, Ji X, Li J, et al. Association between serum $\gamma$-glutamyltransferase and chronic kidney disease in urban Han Chinese: a pro-spective cohort study. Int Urol Nephrol. 2017;49:303-12.

19. Sinn DH, Kang D, Jang HR, Gu S, Cho SJ, Paik SW, et al. Development of chronic kidney disease in patients with non-alcoholic fatty liver disease: a cohort study. J Hepatol. 2017;67:1274-80.

20. Kunutsor SK, Laukkanen JA. Gamma-glutamyltransferase and risk of chronic kid-ney disease: a prospective cohort study. Clin Chim Acta. 2017;473:39-44.

21. Jang HR, Kang D, Sinn DH, Gu S, Cho SJ, Lee JE, et al. Nonalcoholic fatty liver disease accelerates kidney function decline in patients with chronic kidney dis-ease: a cohort study. Sci Rep. 2018;8:4718.

22. Wilechansky RM, Pedley A, Massaro JM, Hoffmann U, Benjamin EJ, Long MT. Relations of liver fat with prevalent and incident chronic kidney disease in the Framingham Heart Study: a secondary analysis. Liver Int. 2019;39:1535-44.

23. Park H, Dawwas GK, Liu X, Nguyen MH. Nonalcoholic fatty liver disease increases risk of incident advanced chronic kidney disease: a propensity-matched cohort study. J Intern Med. 2019:286:711-22.

24. Oniki K, Saruwatari J, Izuka T, Kajiwara A, Morita K, Sakata M, et al. Nakagawa K. Influence of the PNPLA3 rs738409 polymorphism on non-alcoholic fatty liver disease and renal function among normal weight subjects. PLoS One. 2015;10:e0132640.

25. Musso G, Cassader M, Gambino R. PNPLA3 rs738409 and TM6SF2 rs58542926 gene variants affect renal disease and function in nonalcoholic fatty liver disease. Hepatology 2015;62:658-9.

26. Mantovani A, Zusi C, Sani E, Colecchia A, Lippi G, Zaza GL, et al. Association be-tween PNPLA3rs738409 polymorphism decreased kidney function in postmeno-pausal type 2 diabetic women with or without non-alcoholic fatty liver disease. Diabetes Metab. 2019;45:480-7.

27. Sun DQ, Zheng KI, Xu G, Ma HL, Zhang HY, Pan XY, et al. PNPLA3 rs738409 is associated with renal glomerular and tubular injury in NAFLD patients with per-sistently normal ALT levels. Liver Int. 2019;40:107-19.

28. Targher G, Mantovani A, Alisi A, Mosca A, Panera N, Byrne CD, et al. Relationship between PNPLA3 rs738409 polymorphism and decreased kidney function in children with NAFLD. Hepatology. 2019;70:142-53.

29. Marzuillo P, Di Sessa A, Guarino S, Capalbo D, Umano GR, Pedullà M, et al. Non-alcoholic fatty liver disease and eGFR levels could be linked by the PNPLA3 I148M polymorphism in children with obesity. Pediatr Obes. 2019;14:e12539.

30. Di Costanzo A, Pacifico L, D’Erasmo L, Polito L, Martino MD, Perla FM, et al. Nonalcoholic fatty liver disease (NAFLD), but not its susceptibility gene vari-ants, influences the decrease of kidney function in overweight/obese children. Int J Mol Sci. 2019;20.

31. Romeo S, Kozlitina J, Xing C, Pertsemlidis A, Cox D, Pennacchio LA, et al. Genetic variation in PNPLA3 confers susceptibility to nonalcoholic fatty liver disease. Nat Genet. 2008;40:1461-5.

32. Sookoian S, Castaño GO, Burgueño AL, Gianotti TF, Rosselli MS, Pirola CJ. A nonsynonymous gene variant in the adiponutrin gene is associated with nonal-coholic fatty liver disease severity. J Lipid Res. 2009;50:2111-6.

33. Valenti L, Al-Serri A, Daly AK, Galmozzi E, Rametta R, Dongiovanni P, et al. Ho-mozygosity for the patatinlike phospholipase-3/adiponutrin I148M polymor-phism influences liver fibrosis in patients with nonalcoholic fatty liver disease. Hepatology. 2010;51:1209-17.

34. Sookoian S, Pirola CJ. Meta-analysis of the influence of I148M variant of patatin-like phospholipase domain containing 3 gene (PNPLA3) on the suscepti-bility and histological severity of nonalcoholic fatty liver disease. Hepatology. 2011;53:1883-94. 
35. Pirazzi C, Valenti L, Motta BM, Pingitore P, Hedfalk K, Mancina RM, et al. PNPLA3 has retinyl-palmitate lipase activity in human hepatic stellate cells. Hum Mol Genet. 2014;23:4077-85.

36. Kovarova M, Königsrainer I, Königsrainer A, Machicao F, Häring HU, Schleicher E, et al. The genetic variant I148M in PNPLA3 is associated with increased hepatic retinyl-palmitate storage in humans. J Clin Endocrinol Metab. 2015;100:E1568-74.

37. Tian C, Stokowski RP, Kershenobich D, Ballinger DG, Hinds DA. Variant in PNPLA3 is associated with alcoholic liver disease. Nat Genet. 2010;42:21-3.

38. Stickel F, Buch S, Lau K, Meyer zu Schwabedissen H, Berg T, Ridinger M, Rietschel M, et al. Genetic variation in the PNPLA3 gene is associated with alcoholic liver injury in caucasians. Hepatology. 2011;53:86-95.

39. Valenti L, Rumi M, Galmozzi E, Aghemo A, Del Menico B, De Nicola S, et al. Patatin-like phospholipase domain-containing 3 I148M polymorphism, steatosis, and liver damage in chronic hepatitis C. Hepatology. 2011;53:791-9.

40. Muller T, Buch S, Berg T, Hampe J, Stickel F. Distinct, alcohol-modulated effects of PNPLA3 genotype on progression of chronic hepatitis C. J Hepatol. 2011;55:732-3.

41. Speliotes EK, Yerges-Armstrong LM, Wu J, Hernaez R, Kim LJ, Palmer CD, et al; NASH CRN; GIANT Consortium; MAGIC Investigators, Voight BF, Carr JJ, Feitosa MF, Harris TB, Fox CS, Smith AV, et al; GOLD Consortium. Ge-nome-wide association analysis identifies variants associated with nonalcoholic fatty liver disease that have distinct effects on metabolic traits. PLoS Genet. 2011;7:e1001324.

42. Liu DJ, Peloso GM, Yu H, Butterworth AS, Wang X, Mahajan A, et al. Exome-wide association study of plasma lipids in > 300,000 individuals. Nat Genet. 2017;49:1758-66.

43. Hoekstra M, Li Z, Kruijt JK, Van Eck M, Van Berkel TJ, Kuiper J. The expression level of non-alcoholic fatty liver disease-related gene PNPLA3 in hepatocytes is highly influenced by hepatic lipid status. J Hepatol. 2010;52:244-51.

44. Stender S, Kozlitina J, Nordestgaard BG, Tybjærg-Hansen A, Hobbs HH, Cohen JC. Adiposity amplifies the genetic risk of fatty liver disease conferred by multiple loci. Nat Genet. 2017;49:842-47.

45. de Vries AP, Ruggenenti P, Ruan XZ, Praga M, Cruzado JM, Bajema IM, et al; ERA-EDTA Working Group Diabesity. Fatty kidney: emerging role of ectopic lipid in obesity-related renal disease. Lancet Diabetes Endocrinol. 2014;2:417-26.

46. Romeo S, Dongiovanni P, Petta S, Pihalajamaki J, Valenti L. Reply: To PMID 25251399. Hepatology. 2015;62:660.

47. Scorletti E, West AL, Bhatia L, Hoile SP, McCormick KG, Burdge GC, Lillycrop KA, et al. Treating liver fat and serum triglyceride levels in NAFLD, effects of PNPLA3 and TM6SF2 genotypes: results from the WELCOME trial. J Hepatol. 2015;63:1476-83. 